\title{
Hemp-Lime Bio-Composites - Review and Analysis of World-Wide Architectural Examples
}

\author{
$\underline{\text { Michał Gołębiewski }}^{1}$
}

1. Department of Construction, Building Design and Technical Infrastructure, Faculty of Architectue, Warsaw University of Technology, POLAND, Warsaw, Koszykowa 55, E-mail: m.w.golebiewski@gmail.com

\begin{abstract}
The aim of this work is to discuss architectural applications of hemp-lime bio-composite -a sustainable building material with unique properties whose use presents a variety of spatial and technical solutions. This paper provides a brief review of global examples, noting the most interesting projects and analysing the current level of technological development.
\end{abstract}

Keywords - hempcrete, hemp-lime composite, sustainable construction materials

\section{Introduction}

Hemp-lime bio-composites are obtained by mixing hemp shiv, lime-based binder, and water. Since their invention they have become a popular, eco-friendly, low-tech material solution in architectural design due to their unique properties. First, the so-called "hempcrete" has minimal negative impact on the environment: low embodied energy, a low (sometimes even considered negative) carbon footprint [1], and negligible influence on biodiversity - mostly because heavy aggregate is substituted with lightweight hemp shiv obtained from Cannabis Sativa L (industrial hemp). The plant absorbs huge amounts of $\mathrm{CO}_{2}$ [2] during its growth process, its cultivation has only little negative impact on soil and the ecosystem when compared to other crops $[3,4]$, and final processing (decortication and chopping) is strictly mechanical process (no chemicals are used and no waste is produced) [2]. Hydrated lime, the main ingredient in the composition of the binder (among other substances: hydraulic lime, cement, pozzolans, and others), is a source of $\mathrm{CO}_{2}$ emission, which is later reduced by the carbonatation process which occurs in the erect partition. Secondly, physical properties of the material [5]: relatively low thermal conductivity, medium density, and quite high specific heat provide proper thermal insulation and a significant "thermal mass" which stabilizes the interior temperature against daily fluctuations [6]. Heat loss is also minimized by material application techniques which provide air-tightness and reduce thermal bridging. Hygroscopy of the material, which results in high vapor permeability, helps keep the humidity inside at a comfortable level creating favourable microclimatic conditions [7]. No biological [8] (due to vapor permeability and an alkaline environment) nor chemical corrosion was observed and adequate fire resistance of the material was noted [8]. In its typical composition, hempcrete has low mechanical strength, therefore in load-bearing walls it is combined with other structural elements.

\section{Applications}

Hemp has been used by mankind in many industries for ages. One of the oldest documented structural uses of hemp (entire raw plants as well as its processed parts) is hemp-clay/lime plaster in the Ellora caves in India $\left(6^{\text {th }}-11^{\text {th }}\right.$ century). It seems that this material, which has survived for over 1500 years (helping preserve ancient artwork), was used with specific purpose and provided expected favourable interior conditions [9]. Cannabis Sativa fibers were also found in plaster in yet another Indian building - Daulatabad Fort $\left(13^{\text {th }}-16^{\text {th }}\right.$ century) [10]. Many online sources state that the oldest European structure made with the addition of hemp into mortar is the Sarthe river bridge (abutments) in Saint Céneri le Gérei (France) dating back to the Merovingians times. 
Hemp-lime mix was used for the first time in the renovation of the Maison de la Turquie by Charles Rasetti [11] who was working on historical wattle and daub buildings in Champagne (France). The previously used cement-based concrete had only worsened the situation in similar renovations. There was a need for a material able to "breathe", geometrically stable, woodcompatible, and damp resistant. The success of his work led to the increased interest in technology and its use in future restorations of other historical buildings. Many new companies have been founded offering ingredients, ready-made products, and construction services. The growing need to standardize the technology led to the establishment of many associations which are responsible for promoting correct knowledge, technical solutions, and spreading awareness on the topic. Numerous buildings have been renovated in France using this method but the field is always developing as additional old buildings are being subjected to hempcrete renovation in France, the UK, Benelux countries, Germany, among others.

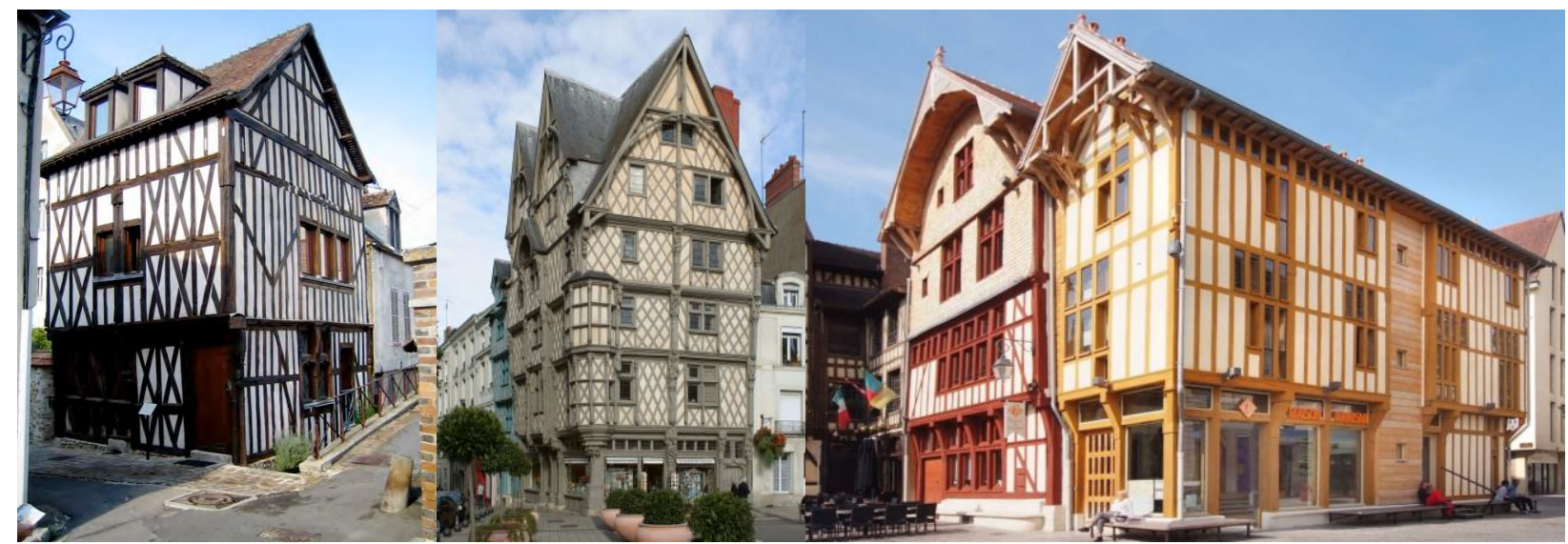

Fig.1,2,3. Examples of historical buildings renovated in France - Maison de la Turquie (on the left) [12], Maison d'Adam (center) [13], Maison du Turisme les Troyes (on the right) [14].

According to [12], the first new structure made of hemp-lime was built in 1989 near Tours (France). Since then, hundreds of hempcrete houses have been built all throughout France. Great Britain is the second country with the fastest spread of the use of this new compound. Singlefamily houses were built mainly in the monolithic technique which is fast, cheap, low-tech, and "do-it-yourself" - the material is manually tamped around the structural frame of 2-sided formwork. In many other countries the development of technology has been limited due to legal regulations whereabout industrial hemp has been incorrectly associated with Cannabis Indica (containing psychoactive substance). The import of hemp was expensive and unjustified from the environmental point of view. For example, hemp cultivation was permitted in Australia in late 1990s, in Canada in 1998, and in the USA in 2014.

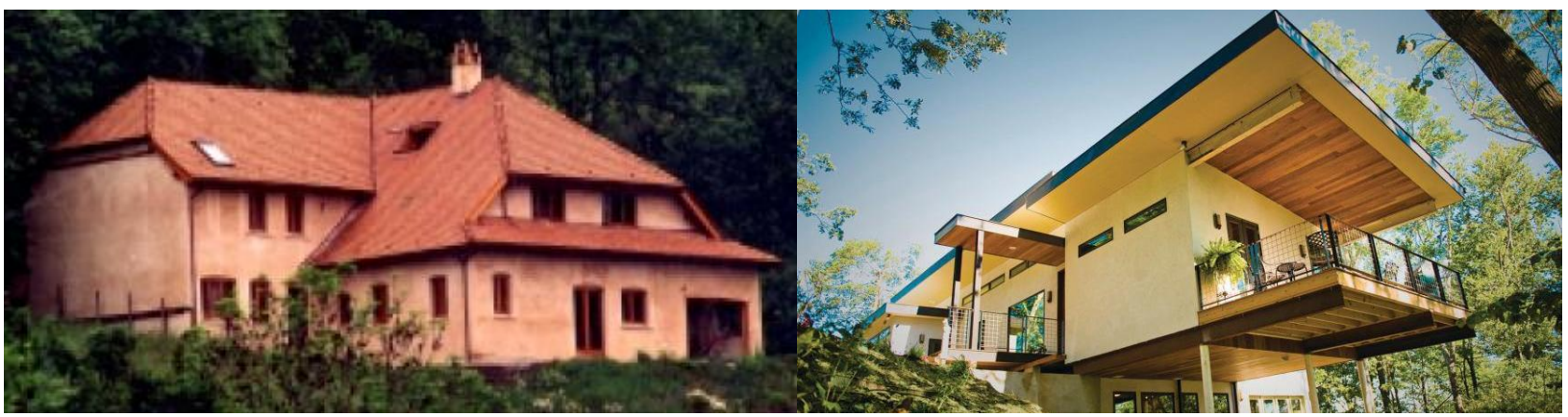

Fig.4,5. Residential house near Tours (on the left) [12], The Push House in Asheville, USA (on the right) [15]. 
Along with hundreds of rather standard typical hempcrete buildings, there are also some architectural structures which, due to their scale, aesthetics, innovative technical solutions, prestige, or promotion have had a very high impact on awareness, on the market, and therefore, the development of technology. Selected examples show a variety of hempcrete uses in architectural design. First in the UK Haverhill houses (2001) provided important results of energy performance tests. Adnams Brewery in Reydon, GB (2006), is considered to be the largest hemp-lime building in existence. A seven-storey public building in Clermont Ferrand, France, was built with use of hempcrete blocks. The Wales Institute for Sustainable Education (2010) combines different eco-friendly material solutions (incl. rammed earth and hempcrete). Hempcrete panels in the archival store in British Science Museum in Wroughton (2012) help provide strictly defined interior conditions. The walls of the Green Gallery in Singapore (2013) unconventionally expose the material on their exterior sides.

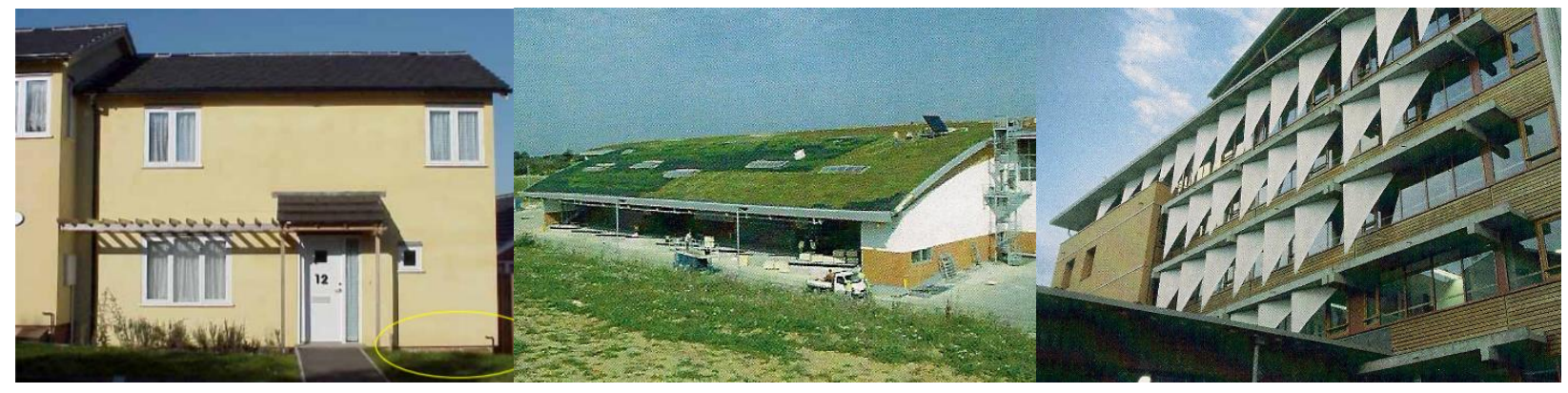

Fig.6,7,8. Haverhill house (on the left) [17], Adnams Brewery (center) [12], Clermont Ferrand, Regional Government Office France (on the right) [12].



Fig.9,10,11. WISE building [18] (on the left) archival store of British Science Museum (center) [19], Green gallery in Singapore [15] (on the right).

Throughout the years hemp-related technology has evolved and became more diverse. Alongside manual tamping, additional techniques have appeared; building with precast blocks, spraying, and prefabrication of entire partitions. Many new uses are up-and-coming, for example, 3D hemp-lime printing or the use of hemp resin for fiber-reinforced resin concrete

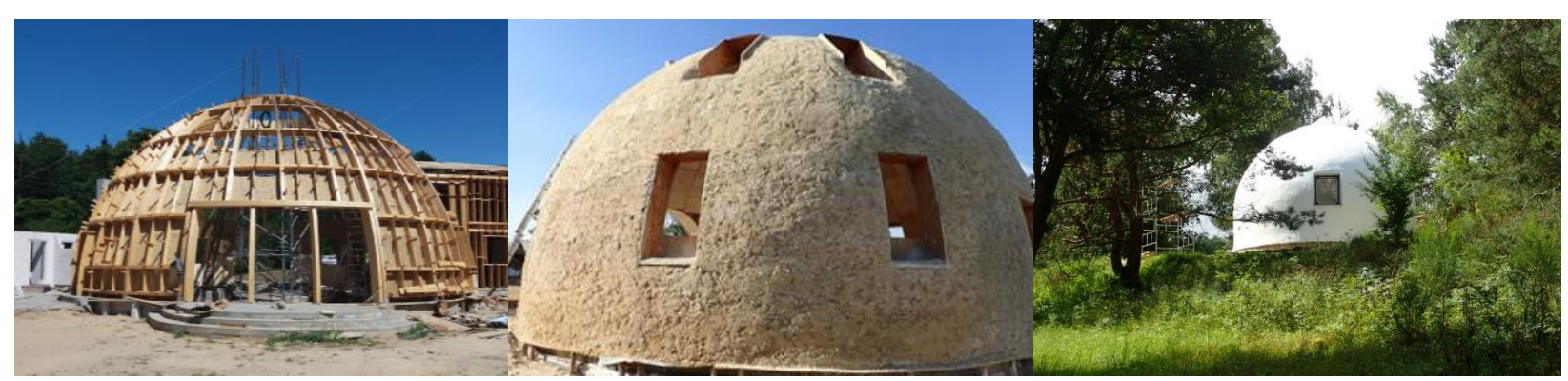

Fig.12,13,14. Hempcrete domes in Poland - under construction (on the left) [20], with hemp applied (center) [20], already finished (on the right) [20]. 


\section{Conclusion}

Ongoing research leads to the conclusion that hempcrete technology nowadays is booming all around the world; it is developing and providing not only sufficient, eco-friendly, and userfriendly building material, but also new spatial and aesthetical design possibilities.

\section{References}

[1] N. Miskin. "The Carbon Sequestration Potential of Hemp - binder. A study of embodied carbon in hemp-binder compared with dry lining solutions for insulating solid walls". Msc. thesis, Centre for Aternative Tchnology, University of East London, London, 2010.

[2] Instytut Włókien Naturalnych i Roślin Zielarskich. Technologia uprawy i przetwórstwa konopi włóknistej. Poznań: IWNiRZ, Poznań, 2013.

[3] EEA (European Environment Agency). "Estimating the environmentally compatible bioenergy potential from agriculture". Internet: https://www.eea.europa.eu/publications/technical_report_2007_12,Technical Report No. 12.2007 [Oct. 23, 2018].

[4] S. Montford, E. Small. "Measuring harm and benefit: The friendliness of Cannabis sativa". Global biodiversity, vol. 8(4), pp. 2-13, 1999.

[5] R. Walker, S. Pavia. "Moisture transfer and thermal properties of hemp-lime concretes". Construction and Building Materials, vol. 64, pp. 270 - 276, 2014.

[6] A. Shea, M. Lawrence, P. Walker. "Hygrothermal performance of an experimental hemplime building". Construction and Building Materials, vol. 36, pp. 270 - 275, 2012.

[7] A. Evrard. "Sorption behaviour of Lime-Hemp Concrete and its relation to indoor comfort and energy demand", PLEA 2006 - The 23rd Conference on Passive and Low Energy Architecture, Geneva, 2006.

[8] R. Bevan, T. Woolley. Hemp Lime Construction: A Guide to Building with Hemp Lime Composites". United Kingdom: Ihs Bre Press, 2010.

[9] M. Singh, M. Sardesai. "Cannabis sativa (Cannabaceae) in ancient clay plaster of Ellora Caves, India". Current Science, vol. 110, no. 5, pp 884 - 889, 2016.

[10] M. Singh, S. Vinodh Kumar. "Mineralogical, Chemical, and Thermal Characterizations of Historic Lime Plasters of Thirteenth-Sixteenth-century Daulatabad Fort, India". Studies in Conservation, vol. 63, pp 482-496, 2018.

[11] P. Bouloc, S. Allegret, L. Arnaud. Hemp: Industrial Production and Uses. France: CABI, 2013.

[12] S. Allin. Building with Hemp. Seed Press, 2012.

[13] Internet: https://fr.wikipedia.org/wiki/Maison_d\%27Adam [Oct. 23, 2018].

[14] Internet: https://www.tourisme-troyes.com [Oct. 23, 2018].

[15] Internet: http://www.hempcretewalls.com/images [Oct. 14, 2018].

[17] BRE, T. Yates. 2002. Final report on the construction of the hemp houses at Haverhill, Suffolk. UK: Building Research Establishment (BRE).

[18] Internet: http://blog.cat.org.uk/2018/06/11/highest-praise-cat-higher-education [Oct. 24, 2018].

[19] Internet: https://blog.sciencemuseum.org.uk for 23 [Oct. 23, 2018].

[20] Internet: http://www.earth-heart.pl/kopula-beton-konopny-hempcrete-dome [Oct. 26, 2018]. 